\title{
Intradural extramedullary primary hydatid cyst of the spine: a case report and review of literature
}

\author{
Iraj Lotfinia · Sima Sayyahmelli • Ata Mahdkhah • \\ M. M. Shoja
}

Received: 21 October 2011/Revised: 5 April 2012/Accepted: 6 May 2012/Published online: 16 June 2012

(C) The Author(s) 2012. This article is published with open access at Springerlink.com

\begin{abstract}
Primary intradural extramedullary hydatid cyst is a rare form of parasitic infection, causing focal neurological signs, commonly observed in sheep-raising areas of the world. We report a rare case of intradural, extramedullary spinal cyst, which we had misdiagnosis in the first surgery, because of rarity of the case. A 55-year-old man presented to our hospital in August 2008. He was admitted to our clinic because of lumbar pain of increasing severity and progressive difficulty with walking and stiffness of both lower limbs, which had lasted for 1 month. On the basis of imaging results, arachnoid cyst of the lumbar spine was diagnosed. Due to rapid progression of the patient's symptoms toward spastic paraplegia, he underwent an emergency surgical decompression procedure. The patient underwent exploratory surgery using a posterior approach. A L1-L2 laminectomy was performed. After opening the dura, an intradural extramedullary cystic mass was determined. The surgical specimen measured $6 \times 2 \mathrm{~cm}$ and was described as a whitish, pearl-like, semitranslucent, cystic material, which was thought to be parasitic. Surgery has to be followed by albendazole therapy.
\end{abstract}

I. Lotfinia $(\bowtie)$

Neuroscience Research Centre, Shohda Hospital,

Tabriz University of Medical Sciences, Tabriz, Iran

e-mail: lotfiniai@yahoo.com

S. Sayyahmelli · A. Mahdkhah

Shohda Hospital, Tabriz University of Medical Sciences,

Tabriz, Iran

M. M. Shoja

Tuberculosis and Lung Diseases Research Center,

Tabriz University of Medical Sciences, Tabriz, Iran
Keywords Hydatid cyst - Spine - MRI - Surgery · Echinococcus granulosus

\section{Introduction}

Hydatid is a Greek word meaning "watery cyst". Hydatid disease is caused by the parasitic tapeworm Echinococcus (E. granulosus, and less commonly E. multilocularis) [1]. Hydatidosis caused by Echinococcus granulosus is an endemic parasitic disease in Mediterranean areas, such as North Africa, Spain, Greece, Turkey, Portugal, Middle East, Australia, New Zealand, South America, Baltic areas, the Philippines, Northern China and the Indian sub-continent [2]. Although the disease is rare in Western Europe and North America [3], but has a worldwide distribution [4] and given the ease of modern travel Echinococcus is a worldwide problem [5].

The most common sites of infection are liver $(75 \%)$, lung $(15 \%)$, brain $(2-4 \%)$, and genitourinary tract (2-3\%) [1]. Only $0.5-3.1 \%$ of patients suffer from bone involvement, half of which occurs in the spine [3]. Spinal hydatid cysts are located most commonly at the thoracic (52\%), followed by the lumbar $(37 \%)$ and then the cervical and sacral levels $[1,6]$. Spine is the most common site for the hydatid disease of the bone [1]. Spinal hydatid cysts account for $1 \%$ of all cases of hydatid disease [7]. Braithwaite and Lees [8] have classified the spinal involvement by hydatid disease in five groups: (1) primary intramedullary hydatid cyst; (2) intradural extramedullary hydatid cyst; (3) extradural intraspinal hydatid cyst; (4) hydatid disease of the vertebrae; (5) paravertebral hydatid disease. The first three types in this group are considered rare. Intradural presentation is extremely rare $[6,7,9]$. Although secondary intradural involvement can occur as a 
consequence of spinal dural injury or also via spread through the subarachnoid space of a ruptured intracranial cyst, primary intradural extramedullary hydatid cysts are extremely uncommon $[1,6,10,11]$. In this paper, we report one case of primary intradural extramedullary hydatid cyst and review literature about the reported cases.

\section{Case report}

Presentation and examination

A 55-year-old man presented to our hospital in August 2008. He was admitted to our clinic because of lumbar pain of increasing severity and progressive difficulty with walking and stiffness of both lower limbs, which had lasted for 1 month.

At that time, he had been complaining of weakness and numbness in both lower limbs, and during the 4 days prior to his presentation at the hospital, he had experienced difficulty with walking. Neurological examination had revealed bilateral lower-extremity weakness and spastic paraparesis. No sphincter disturbances were demonstrated.

He noted neither weight loss nor fever during the last month. A general physical examination revealed no abnormality. His erythrocyte sedimentation rate and C-reactive protein levels as well as the results of other biochemical analyses were normal. The results of all hematological tests had been normal. Chest X-ray study revealed normal findings.

\section{Neuroimaging}

Magnetic resonance imaging of the lumbar spine showed a cystic lesion compressing the thecal sac, involving the L1-L2 (Fig. 1a, b). The lesion was hypointense on T1-weighted images and hyperintense on T2-weighted images. The body of the L1 and L2 vertebrae appeared to be intact. The paraspinal muscles were shown to be intact.

Operation and histopathological examination

On the basis of imaging results, arachnoid cyst of the lumbar spine was diagnosed.

Due to rapid progression of the patient's symptoms toward spastic paraplegia, he underwent an emergency surgical decompression procedure. The patient underwent exploratory surgery using a posterior approach. A L1-L2 laminectomy was performed. After opening the dura, an intradural extramedullary cystic mass was determined. The surgical specimen measured $6 \times 2 \mathrm{~cm}$ and was described as a whitish, pearllike, semitranslucent, cystic material, which was thought to be parasitic.

The cyst was initially aspirated and clear fluid was found. This clear fluid strongly indicated a possibility of hydatid disease; therefore, $3 \%$ hypertonic saline was used to irrigate the operative site and was injected into the cysts. A classic milky-white cyst wall was encountered, confirming our suspicion of a hydatid cyst. The cyst was excised during concurrent steroid therapy to avoid an anaphylactic reaction (Fig. 1c). The entire operative field and surrounding regions were irrigated with hypertonic saline. The wound was closed in layers.

In the histopathological examination, the cyst wall was noted to stain with Hematoxylin and Eosin (H\&E).

There were eosinophilic inflammatory cells in the cyst wall, which supported the presence of a heavy inflammatory reaction, as well as eosinophilic laminar membranous material located in granular eosinophilic debris, which supported a diagnosis of hydatidosis.

\section{Postoperative course}

After the operation, the patient's neurological status improved, and he was discharged with instructions to
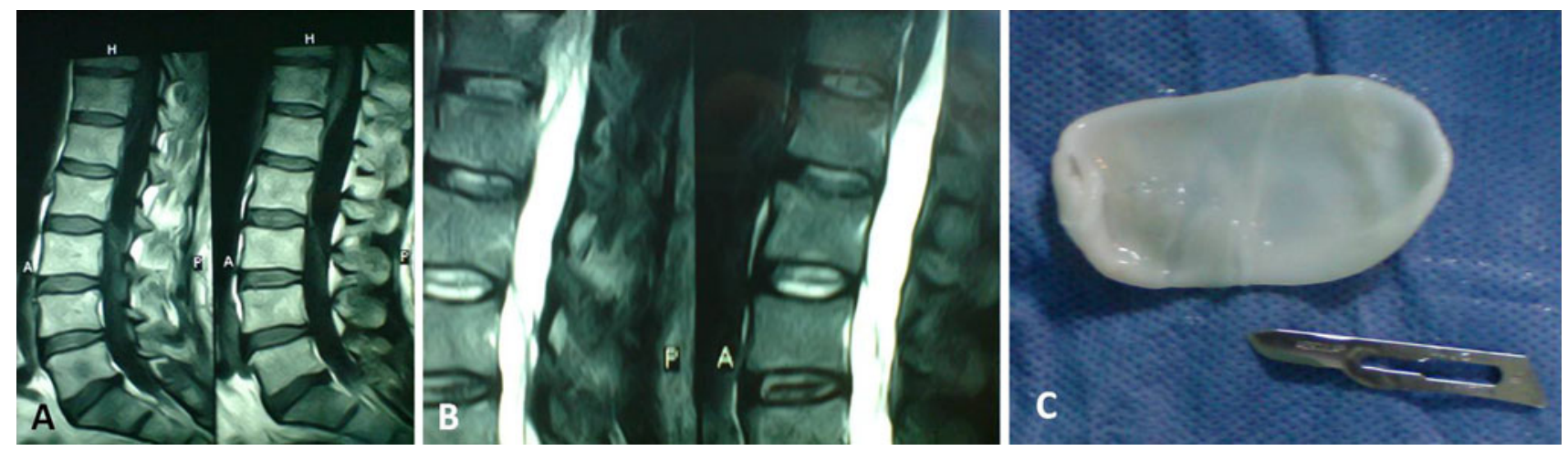

Fig. 1 a, b Magnetic resonance imaging of the lumbar spine showed a cystic lesion compressing the thecal sac, involving the L1-L2. c A classic milky-white cyst wall was excised 
continue a regimen of anthelmintic treatment consisting of albendazole (400 $\mathrm{mg}$ twice a day).

The biopsy specimen results confirmed the diagnosis of hydatid cysts. Neither physical examination nor ultrasonographic examination of the abdominal and pelvic organs demonstrated any localization of disease other than in the spine. Postoperative recovery was uneventful. Over the next 5 months, he made a complete neurological recovery.

\section{Repeated presentation and examination}

The patient returned 6 months later; his chief symptom was back pain that had continued for 1 month, associated with numbness in his bilateral lower extremities. Clinical findings included 4/5 motor strength in the both lower extremity causing a spastic gait. No sphincter disturbances were demonstrated.

\section{Findings on repeated neuroimaging}

On repeated MR imaging, a cystic structure was demonstrated at the L3 level, a level below the prior operated level (Fig. 2a-c). The lesion was hypointense on T1weighted images and hyperintense on T2-weighted images. The postoperative changes were demonstrated at the L1L2 level, due to prior laminectomy. The diagnosis of hydatid cyst was made on the basis of MRl findings and the previous history.

\section{Second operation and postoperative course}

A L3 laminectomy was performed. After opening the dura, an intradural extramedullary cystic mass was determined. The lesion was removed gross totally and the cavity was irrigated with hypertonic saline (Fig. 2d-f).

Histopathological examination revealed an amorphous acellular cuticular lesion compatible with hydatid cyst.

Albendazole treatment was started in the early postoperative stage and three cycles of treatment (each cycle consisted of $15 \mathrm{mg} / \mathrm{kg} /$ day albendazole for 4 weeks) were completed. The postoperative stage was unremarkable without any additional problem.

The patient is currently in his third year of treatment, he has experienced no additional problems. All biochemical

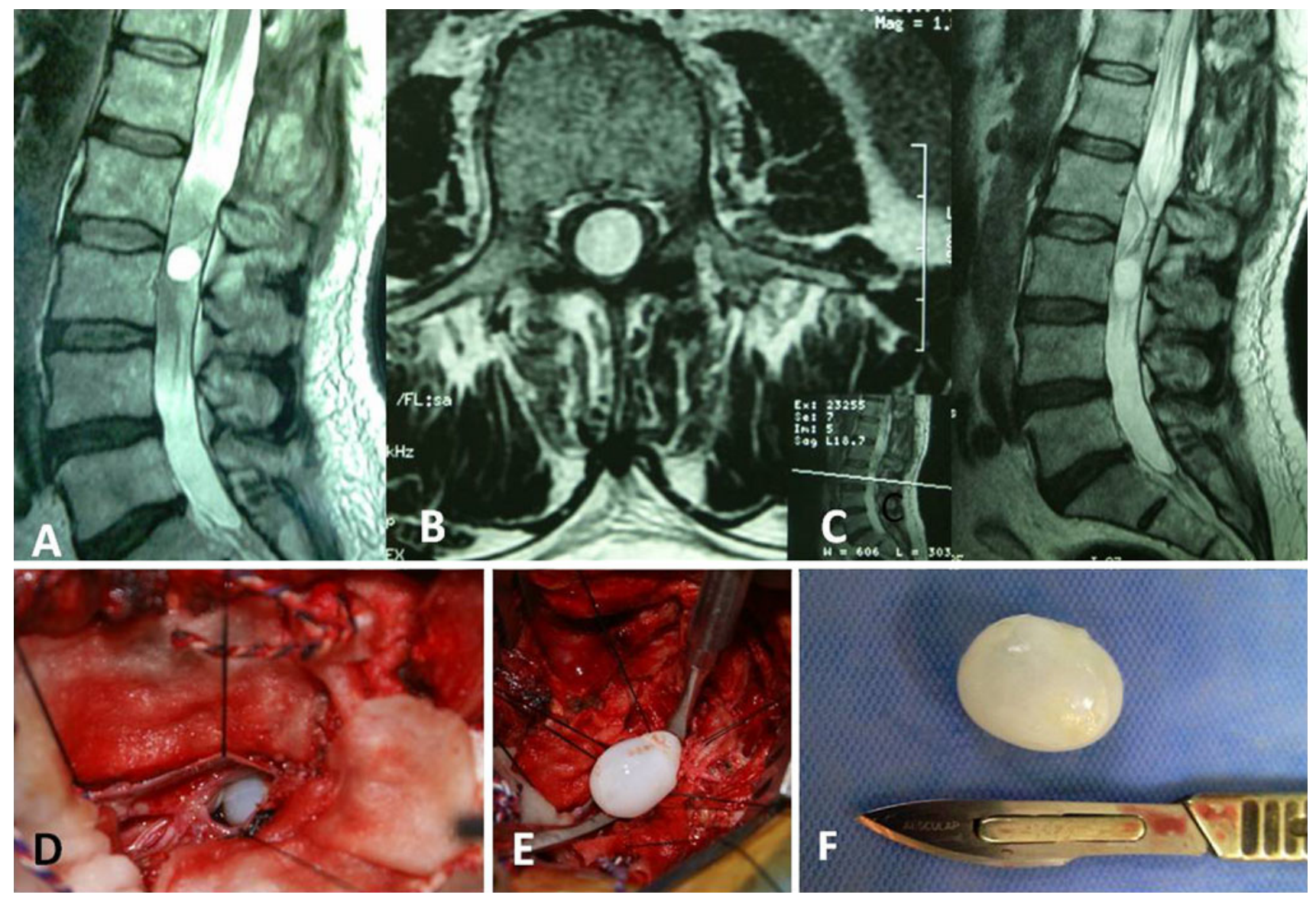

Fig. 2 a-c On repeated MR imaging, a cystic structure was demonstrated at the L3 level, a level below the prior operated level. d-f After opening the dura, an intradural extramedullary cystic mass was determined. The lesion was removed gross totally 
values have remained within normal limits during followup.

\section{Discussion}

Primary intradural extramedullary hydatid cyst is a rare form of parasitic infection, causing focal neurological signs, commonly observed in sheep-raising areas of the world [12]. Cases of cystic hydatid disease are mostly found in areas where dogs and livestock coexist. Although infrequent, infections by cestodes constitute a cause of disease in HIV-infected patients, especially in endemic areas [13]. Adult worms mature in the intestine of the dog, wolf, and other carnivorous animals (definitive host), and the eggs are released in the feces. Intermediate hosts such as sheep and cattle ingest the eggs. Sometimes, humans act as an intermediate host, and contract the disease by means of contamination through the direct contact with the definitive host or its feces or by ingesting food infected with parasite eggs [14]. Once within human or any other intermediate host, the ingested eggs hatch in the duodenum to release oncospheres (true larvae) that burrow into the jejuna submucosa and enter veins or lymphatic vessels [2]. They reach the liver, which acts as an effective filter for most of the larvae. However, if that barrier is overwhelmed, the larvae pass through the inferior vena cava into the right side of the heart and then to the lungs. If the worm is not lodged in liver or lungs, it may be trapped virtually anywhere in the body, such as peritoneum, spleen, kidney, heart, brain, spine, bony skeleton and muscles [3]. The second reported method of human infestation is by inhaling dust carrying dried ova, which hatch in the lungs and form a cyst there [15]. The metacestode cyst develops over a course of years in the patient [16]. Not every larva develops; over $90 \%$ are eliminated by the host reaction. The cysts consist of an outer fibrous layer and a cestodederived inner germinal membrane containing scolices [6, 17]. Human beings are accidental intermediate hosts. Spinal hydatid cysts account for $1 \%$ of all cases of hydatid disease [7]. Hydatid cysts are usually located at the thoracic level (52\%), followed by the lumbar (37\%), and then the cervical and sacral levels [7]. It affects both sexes equally, but is seen more often in the younger population [7]. The route of spread of the disease to the spine is still not fully determined. Schroeder and Medoc [18] believes that the hexacanth embryo reaches bone along a tortuous and complicated systemic circulatory route passing through the liver and lungs. Based on the view of Hernigou [19], spine involvement is more than other bones. This peculiarity is a result of the presence of the Batson venous plexus, in which the blood flows directly from the intestinal vascular bed to the spine without being filtered through the liver or lungs. Paradoxic emboli through that system may be the reason for the occurrence of spine hydatidosis. The other way of spine involvement may be direct extension of a hepatic or pulmonary focus [20]. Intradural extramedullary hydatid cyst can be classified into two groups; primary, in which there is no other site for spreading of parasite to central nervous system. In this form, primary hematic dissemination is regarded as the most plausible mechanism [21]. Investigators believe that approximately $15 \%$ of them pass these barriers and lodge somewhere else in the body [15], and these oncospheres may reach any part of the body such as intradural space. Ley and Marti [22], to explain the intradural location of the cysts secondary to pulmonary location as seen in their patient, postulated that the parasite embryo circulating in the bloodstream enters through an intercostal artery. The secondary form is usually due to rupture of intracranial hydatid cyst and spreading via subarachnoid space during surgery of spontaneously, or spreading from adjacent structures such as spine involvement. Dural tearing during surgery or during an aggressive invasion of spinal space, like lumbar puncture, may have a role in the etiology of the spreading of the infestation into the intradural space [21]. Within 3 weeks, the embryo develops into a larva, and a cyst is formed [23].

Histopathologically, three layers can be identified in the wall of the hydatid cyst: a peripheral adventitial layer which consists of fibrous tissue containing many eosinophils, an intermediate cuticular layer containing amorphousdensely staining laminated chitinous material, and an innergerminal layer that contains nucleated epithelium. It is the germinal layer that gives rise to brood capsules, and scolices (the larval stage of the parasite) develop within these vacuolated structures. The broad capsules (daughter cysts) eventually detach and float freely in the fluid of the hydatid cyst. The number of scolices increases within the daughter cysts over time, causing enlargement of the cyst. The pathology of hydatid disease is caused by the mass effect of the growing cyst [24] so symptoms of spinal hydatid disease are nonpathognomonic, and symptoms are usually related to compression of the spinal cord [7]. Patient may present with symptoms and signs related to spinal cord compression, and due to the relative rarity of the problem the diagnosis was frequently made during surgery [3]. In general, the first symptoms are backache and radicular pain, weaknesses of the limbs occurs in the later phase of the disease [6]. Radiological studies are usually inconclusive but may be helpful in the diagnosis of hydatid disease. Laboratory tests such as ELISA, indirect hemagglutination and complement fixation tests are reported to be $80-100 \%$ sensitive and $88-96 \%$ specific in abdominal disease [3]. However, the sensitivity decreases abruptly to $25-56 \%$ in extrahepatic disease which limits their use in the diagnosis or follow up for primary bone 
Table 1 Cases of intradural extramedullary hydatid cyst which reported

\begin{tabular}{|c|c|c|c|c|c|c|c|}
\hline Authors [References] & Age/sex & Origin & Symptom & Level & $\mathrm{M} / \mathrm{U}$ & $\begin{array}{l}\text { Postoperative } \\
\text { course }\end{array}$ & Recurrence \\
\hline Bartel (1928) [25] & & France & & Cervical & $\mathrm{U}$ & & \\
\hline Rauzier (1928) [25] & & France & & Cervical & $\mathrm{U}$ & & \\
\hline Valle (1928) [25] & & France & & $\begin{array}{l}\text { Cervical, dorsal, } \\
\text { lumbar }\end{array}$ & M & & \\
\hline Deve [26] & & France & & Cervical & $\mathrm{U}$ & & \\
\hline Deve [26] & & France & & Cervical & $\mathrm{U}$ & & \\
\hline Deve [26] & & France & & Cervicodorsolumbar & M & & \\
\hline Diez [27] & & Argentina & & & & & \\
\hline Bertrand et al. [28] & $25 / F$ & Morocco & Paraplegia & $\mathrm{T} 11-\mathrm{T} 12$ & M & Improvement & $\begin{array}{l}\text { Yes/after } \\
13 \text { months }\end{array}$ \\
\hline Boixados [29] & $4 / F$ & Spain & Paraplegia & T5 & $\mathrm{U}$ & Improvement & No \\
\hline Dickmann [30] & & Argentina & & & & & \\
\hline Carrea and Murphy [31] & $9 / \mathrm{F}$ & Argentina & Paraplegia & $\mathrm{T} 4-\mathrm{T} 5$ & $\mathrm{U}$ & Improvement & No \\
\hline Baurand et al. [32] & $35 / F$ & Nord & Paraplegia & T6 & $\mathrm{U}$ & Improvement & No \\
\hline Karvounis et al. [33] & $37 / \mathrm{F}$ & Greece & Sciatica & L5-S1 & M & Improvement & No \\
\hline Bettaieb et al. [34] & $4 / \mathrm{M}$ & Tunisia & Paraplegia & Dorsal high & $\mathrm{U}$ & Improvement & No \\
\hline Bettaieb et al. [34] & $8 / \mathrm{M}$ & Tunisia & Paraplegia & Dorsal high & $\mathrm{U}$ & Improvement & No \\
\hline Bettaieb et al. [34] & $8 / \mathrm{M}$ & Tunisia & Paraplegia & Dorsal medium & $\mathrm{U}$ & Improvement & No \\
\hline Bettaieb et al. [34] & $4 / \mathrm{M}$ & Tunisia & Paraplegia & Dorsal & $\mathrm{U}$ & Improvement & \\
\hline Bettaieb et al. [34] & $8 / \mathrm{M}$ & Tunisia & Paraplegia & Dorsal & $\mathrm{U}$ & Improvement & \\
\hline Bettaieb et al. [34] & $4 / \mathrm{M}$ & Tunisia & Paraplegia & Dorsal & M & Improvement & \\
\hline Sánchez et al. [35] & $62 / \mathrm{F}$ & Spain & Paraplegia & L2 & M & Improvement & No \\
\hline Sharma et al. [36] & $14 / \mathrm{M}$ & India & Paraplegia & T6-T10 & M & Improvement & No \\
\hline Pamir et al. [37] & $34 / F$ & Turkey & Paraplegia & L2 & & No change & \\
\hline Medjek et al. [38] & $21 / \mathrm{F}$ & Algeria & Paraplegia & T12-L1 & $\mathrm{U}$ & Improvement & No \\
\hline Akhan et al. [39] & $6 / \mathrm{M}$ & Turkey & $\begin{array}{l}\text { Paraplegia incontinence } \\
2 \text { month }\end{array}$ & T9-T11 & $\mathrm{U}$ & & \\
\hline İşlekel et al. [40] & 19/M & Turkey & Paraplegia & L2-L4 & M & Improvement & Yes \\
\hline Berk and Erdogan [41] & 17/M & Turkey & $\begin{array}{l}\text { Paraparesis, incontinence, } \\
1 \text { month }\end{array}$ & $\mathrm{T} 7-\mathrm{T} 8$ & M & Improvement & No \\
\hline $\begin{array}{l}\text { Kabbaj-El Kouhen } \\
\text { et al. [42] }\end{array}$ & $6 / \mathrm{M}$ & Morocco & Paraplegia & L1-L3 & M & Improvement & \\
\hline \multirow[t]{2}{*}{ Chat et al. [43] } & $13 / \mathrm{F}$ & Morocco & Paraplegia & $\mathrm{T} 5-\mathrm{T} 11$ & M & Improvement & \\
\hline & & & & L4-L5 & & & \\
\hline Pushparaj et al. [44] & $40 / \mathrm{F}$ & India & Paraplegia & $\mathrm{T} 10-\mathrm{T} 11$ & $\mathrm{U}$ & Improvement & No \\
\hline Chakir et al. [25] & $18 / \mathrm{M}$ & Morocco & Paraplegia & L1-L2 & $\mathrm{U}$ & Improvement & Yes \\
\hline Onbas et al. [9] & 48/M & Turkey & Paraparesis & $\mathrm{C} 7-\mathrm{T} 1$ & M & Improvement & Yes \\
\hline Hilmani et al. [45] & $25 / \mathrm{F}$ & Morocco & Cauda equina syndrome & L3-L5 & M & Improvement & No \\
\hline Kahilogullari et al. [6] & $32 / \mathrm{F}$ & Turkey & Paraparesis, 6 months & L5-S2 & M & Improvement & No \\
\hline Erdoğmus et al. [46] & $43 / \mathrm{F}$ & Turkey & Sciatica, 2 years & T12-L5 & M & & \\
\hline Kalkan et al. [16] & $8 / \mathrm{M}$ & Turkey & Paraparesis & $\mathrm{T} 7-\mathrm{T} 8$ & $\mathrm{U}$ & Improvement & No \\
\hline Shukla et al. [47] & $8 / \mathrm{M}$ & India & Paraparesis & T12-L1 & $\mathrm{U}$ & Improvement & No \\
\hline Secer et al. [48] & $34 / \mathrm{M}$ & Turkey & Paraparesis, 2 month & $\mathrm{T} 11-\mathrm{T} 12$ & $\mathrm{U}$ & Improvement & No \\
\hline Midyat et al. [49] & $13 / \mathrm{F}$ & Turkey & Paraparesis & $\mathrm{T} 10-\mathrm{T} 11$ & M & Improvement & No \\
\hline Süslü et al. [50] & $34 / \mathrm{M}$ & Turkey & Paraparesis & & & & \\
\hline Lakhdar et al. [7] & $22 / / \mathrm{M}$ & Morocco & $\begin{array}{l}\text { Paraparesis, incontinence, } \\
6 \text { months }\end{array}$ & $\mathrm{T} 11$ & M & Improvement & No \\
\hline Lakhdar et al. [7] & $5 / / \mathrm{M}$ & Morocco & $\begin{array}{l}\text { Cauda equina syndrome } \\
\text { paresis, }\end{array}$ & $\mathrm{T} 12-\mathrm{L} 1$ & M & Improvement & No \\
\hline
\end{tabular}


Table 1 continued

\begin{tabular}{|c|c|c|c|c|c|c|c|}
\hline Authors [References] & Age/sex & Origin & Symptom & Level & $\mathrm{M} / \mathrm{U}$ & $\begin{array}{l}\text { Postoperative } \\
\text { course }\end{array}$ & Recurrence \\
\hline Lakhdar et al. [7] & $10 / \mathrm{F}$ & Morocco & $\begin{array}{l}\text { Paraparesis, incontinence, } \\
1 \text { month }\end{array}$ & L2-L5 & $\mathrm{U}$ & Improvement & No \\
\hline Arif and Zaheer [1] & $9 / \mathrm{M}$ & Turkey & Paraparesis 4 months & T12-L3 & $\mathrm{U}$ & Improvement & No \\
\hline Shukla et al. [11] & $5 / \mathrm{M}$ & India & $\begin{array}{l}\text { Paraparesis, incontinence, } \\
4 \text { month }\end{array}$ & L4-S1 & $\mathrm{U}$ & Improvement & No \\
\hline Present case & $55 / \mathrm{M}$ & Iran & Paraparesis, 1 month & L1-L3 & $\mathrm{U}$ & Improvement & Yes \\
\hline
\end{tabular}

$M$ vesicles multiple, $U$ univesicle

disease [3]. The best preoperative diagnostic procedure is MR [23, 51].

Berk et al. [41] reviewed MRI characteristics of the lesions and concluded that they had a unique appearance: a sausage-like shape with two dome-shaped ends, thin and regular walls and no septation or debris in the lumen. The lesions are occasionally spherical. Signal characteristics of the cyst content are usually similar to that of CSF. On T1weighted images, the cyst wall may be isointense or give slightly lower signal than its contents, and T2-weighted images demonstrates a low-intensity rim surrounding the homogeneous high-signal cyst content. The T2-weighted image features indicate the viability of the cyst: a decrease in high signal and increase in low signal from collapsed cyst walls indicate a succumbed cyst. The cyst wall demonstrates slight contrast enhancement. The low-signal rim on T2-weighted images results from reactive fibrosis and degeneration around the parasitic membrane and correlates with the histopathological examination [41]. MRI is also very helpful in early diagnosis of postoperative recurrence. The management of hydatid cyst is always surgery; treatment is mainly total removal without cyst rupture [1, 14]. Careful dissection and irrigation around the cyst is essential to avoid intraoperative cyst rupture, which leads to recurrence $[52,53]$. In addition to recurrence, rupture of a cyst with spillage of the content may provoke a variety of hypersensitivity reactions such as pruritus, urticaria, edema, dyspnea, asthma, vomiting, diarrhea, colicky abdominal pain and even anaphylactic shock [3]. Posterior approach is usually preferred for pure intradural or pure epidural lesions at all the spinal levels [1]. If cysts rupture during intervention, the surgical area should be irrigated with hypertonic saline; however, this seems relatively ineffective, since if any cyst ruptures into the intradural space, recurrence is inevitable [40]. Reports also indicate that irrigating the wound with hypertonic saline or a diluted betadine solution after cyst removal helps osmotically destroy and disrupt the parasites, although this remains unproven [4]. Adjuvant antihelmintic chemotherapy is essential to control the disease locally, to avoid systemic spread, and to prevent recurrence [54, 55]. The poor prognosis may be related to the localization (intradurally or extradurally) of the cyst and weak penetration of antihelminting drug, albendozole, and metabolites into the intradural space by a passive diffusion transport mechanism [51]. Benzimidazoles (albendazole or mebendazole), given alone or combined with praziqantel, are currently used for the treatment of hydatidosis. It should be kept in mind that both of these drugs are teratogenic and embryotoxic, and both may cause alterations in liver function and hematological adverse reactions [3]. Albendazole is preferred over mebendazole due to better pharmacokinetic properties and superior efficacy against helminths [3]. Their action is likely to be parasitostatic rather than parasiticidal [14]. A course of albendazole ( $800 \mathrm{mg}$ daily in two divided doses) is continued for 1 to 6 months (usually 3 months) [3].

Recurrence is very rare with the intradural extramedullary form of hydatid disease [9]. We have to know cystscontaining hydatid sand are fertile cysts. If no sand is present, the cyst is sterile and does not form secondary cysts in case of spillage. It takes 6-9 months for a cyst to become fertile [56]. This delay is important to keep in mind. Patients who experience an intraoperative cyst rupture should be operated on again within that period [15].

In the literature review we found 44 another cases of primary intradural extramedullary hydatid cyst (Table 1), of which in mentioned cases $59.4 \%$ man and $40.6 \%$ women. The youngest patient was 4 and the oldest was 62 years old, and the mean age of reported cases was 20.5 years. So disease is more common in man and young patients. The most common clinical manifestation was paraplegia and after that were paraparesis, incontinence and radicular pain in lower limbs. Duration of symptoms is reported in nine cases, which varied between 1 to 24 months and the mean 5.2 months. The most common site for primary intradural extramedullary hydatid cyst was thoracic $(46.5 \%)$, lumbar $(30.2 \%)$, cervical $(9.3 \%)$ and then thoracolumbar, cervicodorsolumbar and cervicodorsal. Cysts occur in two types, unilocular and multilocular. Unilocular cyst is more common (57.5\%). In most reported patients there is no recurrence and symptoms improved after surgery. 


\section{Conclusion}

Vertebral hydatidosis is a rare but a serious condition, which is frequently misdiagnosed as arachnoid cyst, so in differential diagnosis of intradural arachnoid cyst especially in endemic area, hydatid cyst should be consider. A high index of suspicion combined with good-quality neuroimaging is important for early and correct diagnosis. Total surgical removal of the cysts without rupture should be aimed for. The best treatment remains active nationwide prevention of the disease.

\section{Conflict of interest None.}

Open Access This article is distributed under the terms of the Creative Commons Attribution License which permits any use, distribution, and reproduction in any medium, provided the original author(s) and the source are credited.

\section{References}

1. Arif S, Zaheer S (2009) Intradural extramedullary primary hydatid cyst of the spine in a child: a very rare presentation. Eur Spine J 18(Suppl 2):179-182

2. Thaler M, Gabl M, Lechner R, Gstöttner M, Bach C (2010) Severe kyphoscoliosis after primary Echinococcus granulosus infection of the spine. Eur Spine J 19:1415-1422

3. Pamir M, Zduman K, Elmaci I (2002) Spinal hydatid disease. Spinal Cord 40:153-160

4. Schnepper D, Johnson W (2004) Recurrent spinal hydatidosis in North America. Neurosurg Focus 17(6):E8

5. Lotfinia I, Vahedi P, Hadidchi S, Djavadzadegan H (2007) Multiple cerebral hydatid cysts secondary to embolization from intracardiac hydatidosis. Neurosurg Q 17:134-137

6. Kahilogullari G, Tuna H, Aydin Z, Colpan E, Egemen N (2005) Primary intradural extramedullary hydatid cyst. Am J Med Sci 329(4):202-204

7. Lakhdar F, Arkha Y, Rifi L, Derraz S, Ouahabi A, Khamlichi A (2009) Spinal intradural extramedullary hydatidosis: report of three cases. Neurosurgery 65:372-377

8. Braithwaite P, Lees R (1981) Vertebral hydatid disease: radiological assessment. Radiology 140:763-766

9. Onbas O, Kantarci M, Alper F, Sekmenli N, Okur A (2004) Spinal widespread intradural extramedullary hydatidosis. Neuroradiology 46:310-312

10. Tsitouridis I, Dimitriadis A (1997) CT and MRI in vertebral hydatid disease. Eur Radiol 7:1207-1210

11. Shukla S, Sharma V, Singh K, Trivedi A (2010) Primary lumbosacral intradural hydatid cyst in a child. J Neurosci Rural Pract 1(2): 109-111

12. Turgut AT, Turgut M (2009) Intradural extramedullary primary hydatid cyst of the spine in a child: a very rare presentation. Eur Spine J 18(8):1234-1235; author reply 1236

13. Erayman I, Kalkan E, Erdi F, Kerimoglu U, Esen H (2011) Primary spinal hydatid cyst in a patient with acquired immunodeficiency syndrome. Eur Spine J 20(Suppl 2):S235-S238

14. Baykaner M, Doğulu F, Öztürk G, Edali N, Tali T (2000) A viable residual spinal hydatid cyst cured with albendazole. J Neurosurg Spine 1(93):142-144
15. Haddad F, Haddad G (2005) Hydatid disease of the central nervous system personal experience: its appearance, management, and outcome in the brain and spine. Neurosurg Q 15:33-41

16. Kalkan E, Cengiz S, Onur C, Erdi F, Baysefer A (2007) Primary spinal intradural extramedullary hydatid cyst in a child. J Spinal Cord Med 30:297-300

17. Sparks A, Connor D, Neafie R (1976) Echinococcosis. In: Pathology of tropical and extraordinary diseases, vol 2. AFIP, Washington D.C, pp 530-534

18. Schroeder A, Medoc J (1952) Hydatid disease of the spinal column. J Nerv Ment Dis 116:1025-1045

19. Hernigou P, Nabih A, Goutallier D (1992) Hydatidose vertebrale. complications, apport de l'imagerie moderne. Rev Rhum Mal Osteoartic 59:131-135

20. Lath R, Ratnam B, Ranjan A (2007) Diagnosis and treatment of multiple hydatid cysts at the craniovertebral junction. J Neurosurg Spine 6:174-177

21. Kaen A, Lagares A, Perez-Nuñez A, Rivas J, Ramos A, Lobato R (2009) Intradural extramedullary spinal hydatidosis: case report. Neurocirugía 20:282-287

22. Ley A, Marti A (1970) Intramedullary hydatid cyst. J Neurosurg 33:457-459

23. Moharamzad Y, Hadizadeh H, Shoberi E, Farzanegan G, Hashmi F, Namavari A (2008) Disseminated intraspinal hydatid disease. J Neurosurg Spine 8:490-493

24. Rosenblatt G, Walsh C (2001) Recurrence of genitourinary hydatid cyst after nephrectomy. Infect Urol 14(3):75-79

25. Chakir N, Akhaddar A, Quessar A, Ouahabi A, Elhassani M, Elkhamlichi A (2002) L'hydatidose intradurale extramedullaire primitive. J Neuroradiol (masson paris) 29:177-182

26. Deve (1928) Vertebral echinococcosis, pathogenic process and their lesions [in French]. Ann Anat Path 5:841-859

27. Diez J (1941) Bol Acad Argent Cirug 25:630-640

28. Bertrand J, Acquaviva R, Blavignanc F, Thevenet C (1956) Compression médullaire par échinococcose arachnoïdienne. Maroc Méd 35:320-324

29. Boixados JR (1961) Hidatidosis raqui-medular. Acta Neurochirurgica 9:157-170

30. Dickmann GH (1963) Encephalic and rachidial hydatidosis. In: van Bogaert L, World Federation of Neurology (eds) Tropical Neurology: proceedings of the first international symposium held in Buenos Aires, pp 112-121

31. Carrea R, Murphy G (1964) Primary hydatid cyst of the spinal cord. Acta Neurol Latinoam 10:308-312

32. Baurand C, Daniel F, Guillermain P, Tournigand T, Gascard E (1970) Spinal cord compression by an intra-dural hydatid cyst (apropos of a case) [in French]. Mars Med 107:921-922

33. Karvounis PC, Singounas EG, Tsaprounis G (1977) Intradural spinal echinococcus simulating lumbar disc protrusion. Neurochirurgia (Stuttg) 20:58-60

34. Bettaieb A, Khaldi M, Ben Rhouma T, Touibi S (1978) Spinal echinococcosis; Clinical study of 32 cases (author's transl) [in French]. Neurochirurgie 24:205-210

35. Sánchez L, López J, Aguilar A, Oliva M, Donnay G (1980) Spinal sub-dural hydatidosis. A report on one case (author's transl) [in French]. Neurochirurgie 26:235-238

36. Sharma A, Kashyap V, Abraham J, Kurian S (1981) Intradural hydatid cysts of the spinal cord. Surg Neurol 16:235-237

37. Pamir MN, Akalan N, Ozgen T, Erbengi A (1984) Spinal hydatid cysts. Surg Neurol 21:53-57

38. Medjek L, Zenini S, Hammoum S, Hartani M (1991) Intradural hydatidosis of the thoracic spine. Apropos of a case [in French]. Ann Radiol (Paris) 34:251-255

39. Akhan O, Dincer A, Saati I, Gulekon N, Besim A (1991) Spinal intradural hydatid cyst in a child. Br J Radiol 64:456-466 
40. İşlekel S, Zileli M, Eşahin Y (1998) Intradural spinal hydatid cysts. Eur Spine J 7:162-164

41. Berk C, Erdogan A (1998) MRI in primary intraspinal extradural hydatid disease: case report. Neuroradiology 40:390-392

42. Kabbaj-El Kouhen N, Dafiri R, el Ouahabi A, el Khamlichi A, Imani F (1999) Isolated lumbar intradural hydatid cyst [in French]. J Radiol 80:147-149

43. Chat L, Akjouj M, Chellaoui M, Gueddari F, Alami D, Achaâban F, Najid A, Benamour-Ammar H (2000) Spinal intradural hydatid cyst [in French]. J Radiol 81:535-537

44. Pushparaj K, Sundararajan M, Madeswaran K, Ambalavanan S (2001) Primary spinal intradural hydatid cyst-a short report. Neurol India 49:203

45. Hilmani S, El Malki M, Bertal A, Achouri M, Sami A, Ouboukhlik A (2004) Lumbar intradural hydatid cyst. Case report [in French]. Neurochirurgie 50:57-60

46. Erdoğmus B, Yazıcı B, Özdere B (2005) Magnetic resonance imaging of primary intradural extramedullary thoracolumbar hydatid cyst. Eur J Gen Med 2(2):86-88

47. Shukla S, Trivedi A, Singh K, Sharma V (2008) Craniospinal hydatidosis: report of three cases. J Pediatr Neurosci 3:146-149

48. Secer H, Anik I, Celik E, Daneyemez M, Gonul E (2008) Spinal hydatid cyst mimicking arachnoid cyst on magnetic resonance imaging. J Spinal Cord Med 31(1):106-108
49. Midyat L, Gökçe S, Onder A, Ozdemir Y, Mursalov G, Mir S (2009) A very rare cause of childhood paraparesis: primary intradural extramedullary spinal hydatid cyst. Pediatr Infect Dis J 28(8):754-755

50. Süslü H, Çeçen A, Börekci A, Bozbuga M (2009) Primary spinal hydatid disease. Turkish Neurosurgry 19(2):186-189

51. Güneçs M, Akdemir H, Tuğcu B, Günaldi Ö, Gümüçs E, Akpinar A (2009) Multiple intradural spinal hydatid disease: a case report and review of literature. Spine 34:E346-E350

52. Taghipour M, Zamanizadeh B, Bagheri M, Zare Z (2005) Hydatid cyst of the foramen magnum case report. Neurosurg Q 15:110-112

53. Prabhakar M, Acharya A, Modi D, Jadav B (2005) Spinal hydatid disease: a case series. J Spinal Cord Med 28:426-431

54. Bonifacino R, Dogliani E, Craig PS (1997) Albendazole treatment and serological follow-up in hydatid disease of bone. Int Orthop 21:127-132

55. García R, Carvajal I, Ortiz-García A (2000) Primary solitary Echinococcosis in cervical spine. Postsurgical successful outcome after long-term albendazole treatment. Spine 25:520-523

56. Araj G, Matossian R, Malakian A (1977) The host response in secondary hydatidosis of mice. Cell Mediat Immun 52:31-38 